\title{
In vitro Cytotoxic and Antioxidant Activities of Careya arborea Root Extracts
}

\author{
Bandenawaz Ramdurga ${ }^{1, *}$, Rakesh Kumar Jat ${ }^{2}$, Shrishailappa Badami ${ }^{3}$ \\ 'Department of Biological Sciences, Baze University, Abuja, NIGERIA. \\ 2Department of Pharmaceutical Sciences, JJT University, Chudela, Rajasthan, INDIA. \\ ${ }^{3}$ Department of Phytochemistry and Pharmacology, Radiant Research Laboratories Pvt. Ltd., Bangalore, Karnataka, INDIA.
}

\begin{abstract}
Background: Careya arborea stem bark extracts were reported earlier by one of us to possess cytotoxic, antioxidant and anticancer properties. Since, the root of the plant has not been studied biologically so far, the present study was aimed. Similar to stem bark, the root of the plant may also possess anticancer properties. This is the preliminary study. Materials and Methods: A crude methanol and four successive extracts of root were examined for cytotoxic activity against five cancerous cell lines and antioxidant activity using standard methods. $I C_{50}$ values were found out to judge the activity. Results: The crude methanol extract showed strong cytotoxicity with $I_{50}$ values ranging from $46.49 \pm 0.4$ to $54.73 \pm 3.3 \mu \mathrm{g} /$ $\mathrm{ml}$ against all the cell lines. The successive petroleum ether extract also showed similar property against these cell lines with $I C_{50}$ values ranging
\end{abstract}

from $48.84 \pm 1.3$ to $75.57 \pm 1.8 \mu \mathrm{g} / \mathrm{ml}$. The crude methanol extract was also found to possess potent activity in most of the antioxidant methods. Conclusion: The study supports the traditional use of the plant for anticancer purposes and the extract merit further studies.

Key words: Medicinal plants, Anticancer, Cytotoxicity, Phytochemicals.

Correspondence

Bandenawaz Ramdurga

Department of Biological Sciences, Baze University, Abuja, NIGERIA.

Phone no: +919972669021

Email: bandenawazramadurg@gmail.com

DOI: 10.5530/ijpi.2021.1.24

\section{INTRODUCTION}

Careya arborea Roxb. (family: Barringtoniaceae) stem bark is traditionally used against cancer and other purposes. ${ }^{1,2}$ Several steroids, saponins, flavonoids, tannins and alkaloids have been isolated from its various parts. ${ }^{3,4}$ Its hepatoprotective, antitumor, CNS depressant, anti-diarrheal, anticonvulsant, wound healing, gastro protective, antioxidant and other biological activities are well known. ${ }^{5,6}$ Antimicrobial activity of its fruits, ${ }^{7}$ leaves $^{8}$ and stem bark extracts ${ }^{9}$ have also been reported. However, so far its root has not been studied for its pharmacological properties.

Today, wide spread cancer around the world and due to the side effects of modern treatments, patients are being attracted more towards herbal medicines ${ }^{10,11}$ due to the common mind set of people towards them as safe, effective, user friendly and lack of side effects. Herbal antioxidants are also in demand around the world for their free radical scavenging effects and due to their beneficial use in improving health of an individual. ${ }^{5,6}$ One of the other characteristics attributed to antioxidants is that they decrease the risk of suffering cancer. Many of the herbal anticancer products are also known to exhibit cytotoxic and antioxidant properties. ${ }^{6}$ Therefore, the present study was aimed to screen five different extracts of the root for its in vitro cytotoxic and antioxidant activities.

\section{MATERIALS AND METHODS}

\section{Collection and extraction}

Careya arborea root was collected from Haridravati village, Hosanagar, Shimoga dist., Karnataka State, India and identified by Botanist of Survey of Medicinal Plants and Collection Unit, Ooty, Tamil Nadu (voucher no.8570). The shade dried root was powdered and extracted by Soxhlet method (300 g) with methanol (2.5 Litres) for $12 \mathrm{~h}$. After evaporation of the solvent under vacuum at $50-60^{\circ} \mathrm{C}$, the extract yielded a brown residue $59.25 \mathrm{~g}, 19.75 \%$.
The root powder was also extracted $(350 \mathrm{~g})$ in a Soxhlet apparatus successively with non-polar to polar solvents ( 1.75 Litres, each) for 12 $\mathrm{h}$ and the extracts were concentrated. Yields, successive petroleum ether extract, yellowish semisolid residue, $2.94 \mathrm{~g}, 0.84 \%$, chloroform extract, yellowish brown solid, $1.47 \mathrm{~g}, 0.42 \%$, successive ethyl acetate extract, brown solid, $3.47 \mathrm{~g}, 0.99 \%$ and successive methanol extract, brown solid, $22.9 \mathrm{~g}, 6.54 \%$. The extracts were stored in a closed vessel in a refrigerator. A schematic representation of the extraction method is shown in Figure 1.

\section{Preparation of solutions}

Solutions of the extracts were prepared by dissolving in dimethyl sulphoxide (DMSO). For Cytotoxicity studies, $1 \mathrm{mg} / \mathrm{ml}$ stock solution was made by diluting with media used, which was supplemented with $2 \%$ inactivated FBS, sterilized by filtration and serial two fold dilutions were used.

\section{In vitro cytotoxic activity}

The assay was carried out using U87 (Human Glioblastoma), HeLa (Human cervical cancer), HCT 116 (Human colon cancer), MCF 7 (Human breast cancer) and A549 (Human Lung carcinoma) cell lines, which were sourced from National Centre for Cell Sciences, Pune, India and Pasteur Institute of India, Coonoor, Tamil Nadu, India.

After trypsinization of the monolayer cell culture, using MEM/DMEM medium containing $10 \%$ FBS, the cell count was adjusted to $1.0 \times 10^{5}$ cells/ $\mathrm{ml}$. The assay was carried out in 96 well microtiter plate. The diluted cell suspension $(100 \mu \mathrm{l})$ containing approximately 10,000 cells/well was added to each well of the microtiter plate. When a partial monolayer was formed after about $24 \mathrm{hr}$, the top layer was removed and the monolayer was washed once with medium. The extracts $(100 \mu \mathrm{l})$ of different 
concentrations prepared in maintenance media were added to the partial monolayer in each well of microtiter plates.

The microtiter plates were then incubated for 3 days at $37^{\circ} \mathrm{C}$ in $5 \% \mathrm{CO}_{2}$ atmosphere and observed under microscope every $24 \mathrm{hr}$ and recorded. The extract solutions in the microtiter plates were discarded and $50 \mu \mathrm{l}$ of MTT $(2 \mathrm{mg} / \mathrm{ml})$ in MEM-PR (MEM without phenol red) was added to each well. The plates were tilted lightly and incubated at $37^{\circ} \mathrm{C}$ for 4 $\mathrm{hr}$ in 5\% $\mathrm{CO}_{2}$ atmosphere. The plates were removed from the incubator and the supernatant was removed. $50 \mu \mathrm{l}$ of isopropanol was added and the plates were again shaken to solubilize the formed formazan. The absorbance of each well was measured using a microplate reader at a wavelength of $540 \mathrm{~nm}$. The percentage growth inhibition was calculated using the following formula and concentration of drug or test extract needed to inhibit cell growth by $50 \%$ values were generated from the dose-response curves for each cell line. ${ }^{12,13}$ Schematic representation of MTT assay is shown in Figure 2.

$\%$ Growth Inhibition $=100-\left[\frac{\text { Mean OD of individual test group }}{\text { Mean OD of control group }}\right] \times 100$

In vitro antioxidant activity

It was carried out using ABTS, DPPH, nitric oxide scavenging and total antioxidant capacity methods. ${ }^{5}$

\section{ABTS method}

A solution ( $2 \mathrm{mM}$ concentration) of ABTS (54.8 $\mathrm{mg}$ ) was prepared by dissolving in $50 \mathrm{ml}$ of distilled water and potassium per sulphate (17 $\mathrm{mM}, 0.3 \mathrm{ml}$ ) was added. The reaction mixture was kept in dark at room temperature and allowed to stand overnight before use. To $0.2 \mathrm{ml}$ of various concentrations of the extracts, $1.0 \mathrm{ml}$ of distilled DMSO and 0.16
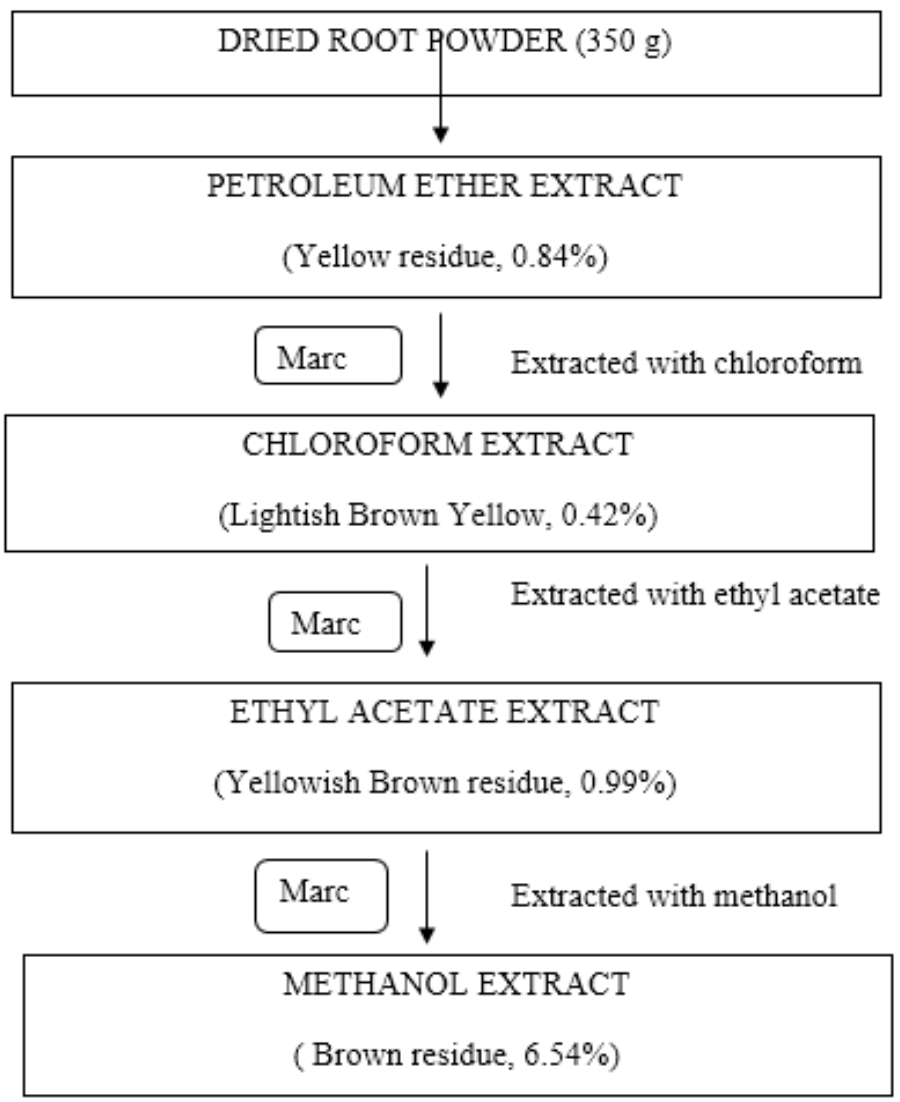

Figure 1: Schematic representation of the successive extraction of root of Careya arborea.

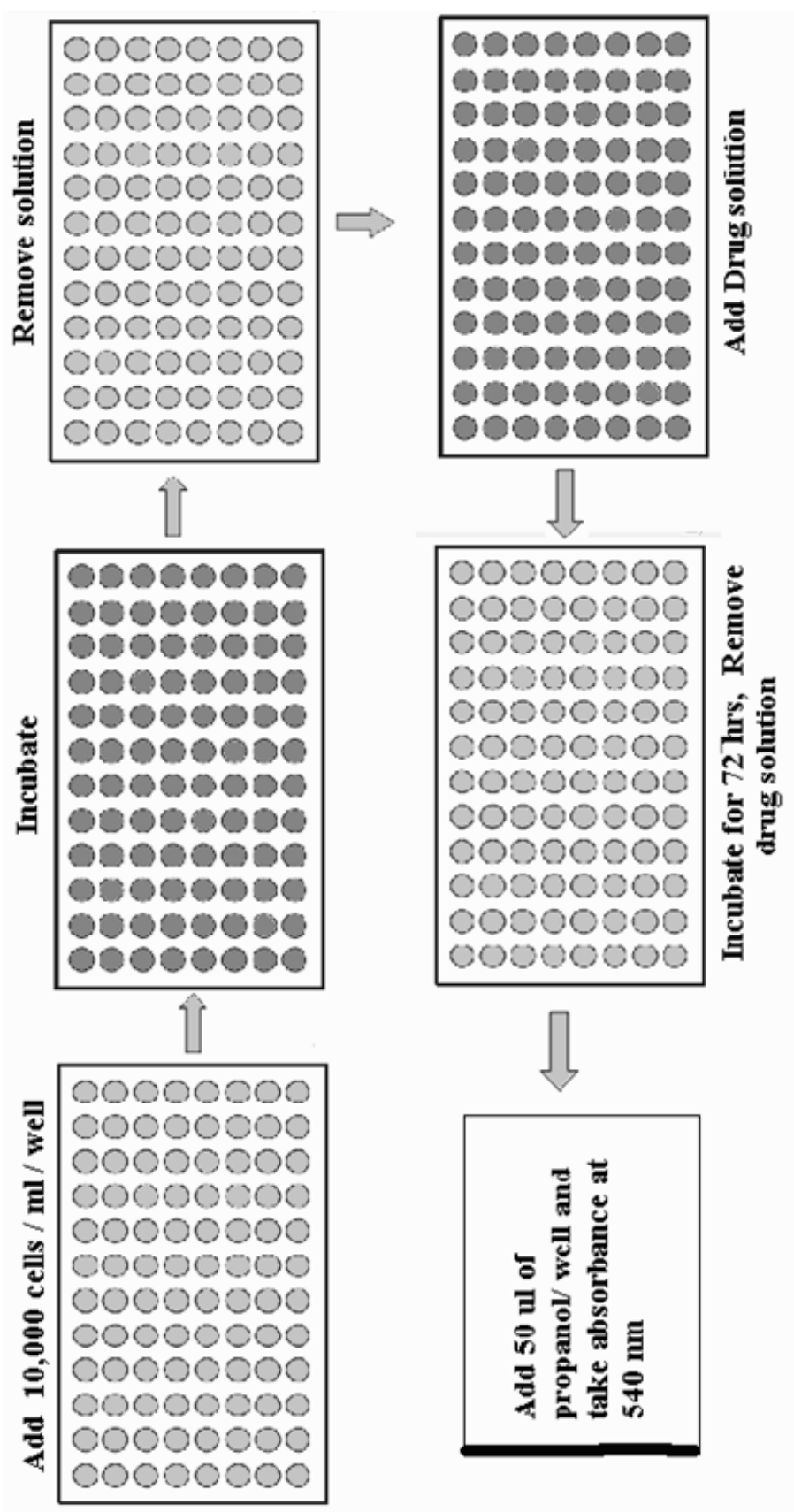

Figure 2: Schematic presentation of MTT assay.

$\mathrm{ml}$ of ABTS solution were mixed to get $1.36 \mathrm{ml}$, kept for $20 \mathrm{~min}$ and absorbance was measured spectrophotometrically at $734 \mathrm{~nm}$.

\section{DPPH method}

DPPH $(200 \mu \mathrm{l})$ solution was mixed with $10 \mu \mathrm{l}$ of each of the test sample solution separately in wells of the microtitre plate. The final concentrations of the test solutions used were in the range of 1000 to $7.812 \mu \mathrm{g} / \mathrm{ml}$. Afterwards, the plates were incubated at $37^{\circ} \mathrm{C}$ for $30 \mathrm{~min}$ and the absorbance of each solution was measured at $490 \mathrm{~nm}$, using a microplate reader.

Nitric oxide method

Sodium nitroprusside $(10 \mathrm{mM}, 4 \mathrm{ml})$ and phosphate buffer saline (PBS, $\mathrm{pH} 7.4,1 \mathrm{ml}$ ) was added to the extract in DMSO at various concentrations 
$(1 \mathrm{ml})$ or standard $(1 \mathrm{ml})$. The solutions were incubated at $25^{\circ} \mathrm{C}$ for 150 min. Afterwards, $0.5 \mathrm{ml}$ was pipetted out, which contains nitrite ions. Diazotization reaction was carried out by adding sulphanilamide reagent $(1 \mathrm{ml})$, shaken well and waited to stand for $5 \mathrm{~min}$. Then, $1 \mathrm{ml}$ of NEDD was added, shaken and allowed to stand for $30 \mathrm{~min}$ in diffused light. The chromophore formed was a pink coloured solution, the absorbance of these solutions was measured at $540 \mathrm{~nm}$.

\section{Total antioxidant capacity method}

Sample solution $(0.1 \mathrm{ml})$ in DMSO, which contains a reducing species was pipetted and mixed with $1 \mathrm{ml}$ of reagent solution containing 0.6 M Sulphuric acid, $28 \mathrm{mM}$ sodium phosphate and $4 \mathrm{mM}$ ammonium molybdate in an Eppendorff tube. The Eppendorff tubes were capped and heated at $95^{\circ} \mathrm{C}$ in water bath for $90 \mathrm{~min}$. The tubes were cooled to room temperature and the absorbance of each solution was measured at $695 \mathrm{~nm}$. The total antioxidant capacity was expressed as mcg equivalent of ascorbic acid

The inhibition percentage of the free radical in each method was calculated using the following formula and the $\mathrm{IC}_{50}$ value was calculated.

Radical scavenging activity $(\%)=\frac{\mathrm{OD}_{\text {control }}-\mathrm{OD}_{\text {sample }}}{\mathrm{OD}_{\text {control }}} \times 100$

Total phenol content of the extracts by using the Folin-Ciocalteu method and the flavonoid content by using Vanillin reagent method ${ }^{14}$ were determined.

\section{RESULTS}

\section{Cytotoxic activity}

The $\mathrm{IC}_{50}$ values were ranging from $46.49 \pm 0.4$ to $54.73 \pm 3.3 \mu \mathrm{g} / \mathrm{ml}$ for the crude methanol extract indicating its potent cytotoxicity against all the tested cell lines with (Table 1). The successive petroleum ether extract also showed potent activity against all the cell lines with $\mathrm{IC}_{50}$ values ranging from $48.84 \pm 1.3$ to $75.57 \pm 1.8 \mu \mathrm{g} / \mathrm{ml}$. These values for the successive ethyl acetate extract which showed moderate cytotoxicity were ranging from $233.21 \pm 2.1$ to $552.11 \pm 5.5 \mu \mathrm{g} / \mathrm{ml}$. The successive methanol extract exhibited weak cytotoxicity with lower values ranging from $607.44 \pm 5.6$ to $724.85 \pm 3.5 \mu \mathrm{g} / \mathrm{ml}$. Among the four cell lines U87 was found to be most susceptible and A549 the least.

\section{Antioxidant activity}

The crude methanol extract was found to be most active among the extracts with low $\mathrm{IC}_{50}$ values in most of the methods (Table 2). The $\mathrm{IC}_{50}$ values for the extract in ABTS and DPPH were found to be $20.55 \pm 0.66$, $305.48 \pm 4.59 \mu \mathrm{g} / \mathrm{ml}$ and total antioxidant capacity was found to be 225.34 $\pm 2.296 \mu \mathrm{g} / \mathrm{ml}$, respectively. The successive ethyl acetate extract was also found to be potent with values of $21.41 \pm 0.60,348.62 \pm 3.35$ and 173.855 $\pm 3.646 \mu \mathrm{g} / \mathrm{ml}$, respectively in these methods. The successive methanol and chloroform extracts have also shown potent activity with $\mathrm{IC}_{50}$ values of $33.95 \pm 0.78$ and $68.56 \pm 1.23 \mu \mathrm{g} / \mathrm{ml}$ in ABTS and $173.855 \pm 3.646$ and $137.16 \pm 3.342 \mu \mathrm{g} / \mathrm{ml}$ in total antioxidant capacity methods, respectively.

Table 1: Cytotoxic activity of various extracts of Careya arborea root against various cell lines.

\begin{tabular}{ccccccc}
\hline \multirow{2}{*}{ SI. No } & \multirow{2}{*}{ Extract } & U87 & HeLa & HCT 116 & MCF 7 & A549 \\
\cline { 3 - 6 } & & Successive \\
\hline & Petroleum Ether & $48.84 \pm 1.3$ & $75.57 \pm 1.8$ & $66.93 \pm 3.6$ & $66.38 \pm 1.0$ & $72.45 \pm 1.3$ \\
1 & $>1000$ & $>1000$ & $>1000$ & $>1000$ & $>1000$ \\
2 & Chloroform & $378.72 \pm 5.1$ & $361.10 \pm 4.6$ & $233.21 \pm 2.1$ & $335.35 \pm 4.5$ & $552.11 \pm 5.5$ \\
3 & Ethyl acetate & $676.56 \pm 2.6$ & $607.44 \pm 5.6$ & $643.92 \pm 3.0$ & $713.07 \pm 4.7$ & $724.85 \pm 3.5$ \\
4 & Methanol & Crude & & \\
& & $47.61 \pm 1.7$ & $47.51 \pm 1.7$ & $47.47 \pm 1.1$ & $46.49 \pm 0.4$ & $54.73 \pm 3.3$ \\
\hline
\end{tabular}

${ }^{\star}$ Average of 12 determinations

Table 2: In vitro antioxidant activity and total phenol and flavonoid contents of various extracts of Careya arborea root

\begin{tabular}{|c|c|c|c|c|c|c|}
\hline \multirow{2}{*}{ Samples } & \multicolumn{3}{|c|}{$\mathrm{IC}_{50}$ values $\mu \mathrm{g} / \mathrm{ml}$ by Methods } & \multirow{2}{*}{ TAC * } & \multirow{2}{*}{$\begin{array}{c}\text { Total } \\
\text { Phenol }^{\mathrm{a}}\end{array}$} & \multirow{2}{*}{$\begin{array}{c}\text { Total } \\
\text { Flavonoid }\end{array}$} \\
\hline & NO & ABTS & DPPH & & & \\
\hline $\begin{array}{l}\text { Successive } \\
\text { Pet ether }\end{array}$ & $>1000$ & $505.23 \pm 5.76$ & $>1000$ & $39.33 \pm 0.296$ & 14.65 & 2.52 \\
\hline Chloroform & $>1000$ & $68.56 \pm 1.23$ & $974.25 \pm 4.12$ & $137.16 \pm 3.342$ & 51.41 & 27.57 \\
\hline Ethyl acetate & $>1000$ & $21.41 \pm 0.60$ & $348.62 \pm 3.35$ & $173.855 \pm 3.646$ & 73.59 & 35.16 \\
\hline Methanol & $>1000$ & $33.95 \pm 0.78$ & $694.08 \pm 4.53$ & $158.00 \pm 2.904$ & 68.97 & 34 \\
\hline $\begin{array}{l}\text { Crude } \\
\text { Methanol }\end{array}$ & $>1000$ & $20.55 \pm 0.66$ & $305.48 \pm 4.59$ & $225.34 \pm 2.296$ & 78.47 & 39.64 \\
\hline
\end{tabular}

${ }^{a}$ The total phenol content of the extract was determined and expressed as gallic acid equivalent in $\mathrm{mg} / \mathrm{g}$ of the extract.

${ }^{b}$ The Flavonoid content of the extract was determined and expressed as Phloroglucinol equivalent in $\mathrm{mg} / \mathrm{g}$ of the extract.

*The total antioxidant (TAC) capacity was expressed as mcg equivalent of ascorbic acid. 
The successive petroleum ether extract has shown least activity among all the extracts. The extracts didn't show any activity in scavenging of nitric oxide. The contents of total phenol and flavonoid were the highest in crude methanol extract, followed by the successive ethyl acetate, methanol and chloroform extracts. The successive petroleum ether extract was found to have very low contents.

\section{DISCUSSION}

Medicinal plants with potential biological properties are considered as the alternatives to the modern drugs in not only treating diseases, but also for their prevention. Plants possessing both anticancer and antioxidant properties can be used as adjuvants along with modern medicines. ${ }^{10,15}$ Many parts of the plant Careya arborea are being used against tumours traditionally in India. ${ }^{2}$ Its stem bark extracts were found to possess potent in vitro antioxidant, cytotoxic and in vivo anticancer properties. ${ }^{5,6}$ In the present study, the crude methanol and successive petroleum ether extracts were found to possess strong cytotoxic properties. The crude methanol and successive methanol and ethyl acetate extracts were shown to possess strong antioxidant properties. Hence, the polar extracts showed potent cytotoxic and antioxidant activities when compared to non-polar extracts. The qualitative phytochemical analysis of the crude methanol extract showed the presence of saponins, flavonoids, glycosides, phenolics, tannins, phytosterols and triterpenoids. The total phenol and flavonoid contents of the crude methanol extract were found to be high indicating that these may be the active phytoconstituents of the extract.

\section{CONCLUSION}

Similar to stem bark, the crude methanol extract of the root of Careya arborea showed strong cytotoxic and antioxidant activities indicating many parts of the plant may possess anticancer properties and further studies are needed in animal models and to isolate the phytochemicals responsible for the activities.

\section{CONFLICT OF INTEREST}

The authors declare no Conflict of interest.

\section{ABBREVIATIONS}

CNS: Central nervous system; DMSO: Dimethyl suphoxide; FBS: Fetal blood serum; MTT: 3-(4,5-Dimethylthiazol-2-yl)-2,5-diphenyl tetrazolium bromide; MEM: Minimum Essential Medium; U87: Human Glioblastoma; HeLa: Human cervical cancer; HCT 116: Human colon cancer; MCF 7: Human breast cancer; A549: Human Lung carcinoma; NO: Nitric oxide; ABTS: 2,2'-Azino-bis(3-ethylbenzothiazoline-6sulfonic acid; DPPH: 2,2-Diphenyl-1-picrylhydrazyl; TAC: Total antioxidant capacity.

\section{REFERENCES}

1. Kirtikar KR, Basu BD. Indian Medicinal Plants. $2^{\text {nd }}$ Ed. Dehradun, India: Bishen Sing Mahendra Pal Sing. 1987;1061-3.

2. Yoganarasimhan SN. Medicinal Plants of India-Karnataka, Bangalore: Interline Publication. 1996.

3. Ahmed M, Rahman MW, Rahman MT, Hossain CF. Analgesic principle from the bark of Careya arborea. Pharmazie. 2002;57(10):698-701.

4. Talapatra B, Basak A, Talapatra SK. Terpenoids and related compounds. Part XX. Careaborin, a new triterpene ester from the leaves of Careya arborea. J Indian Chem Soc. 1981;58:814-5.

5. Natesan S, Badami S, Cherian MM, Hariharapura RC. Potent in vitro cytotoxic and antioxidant activity of Careya arborea bark extracts. Phytother Res. $2007 ; 21(5): 492-5$

6. Natesan S, Badami S, Dongre SH, Godavarthi A. Antitumor activity and antioxidant status of the methanol extract of Careya arborea bark against Dalton's lymphoma ascites-induced ascitic and solid tumor in mice. J Pharmacol Sci. 2007b;103(1):12-23

7. Prabhakaran M, Reejo B, Suresh KD. Antibacterial activity of the fruits of Careya arborea Roxb. (Lecythidaceae). Hygeia J Drugs Medicine. 2014;6(1):20-4.

8. Rathod SB, Hajare SW, Kukade SV, Rothe SP, Wadegaonkar PA. Studies on antitumor and antibacterial activities of Careya arborea Roxb. in vitro. Int J Pharma and Chem Sci. 2013;4:1746-51.

9. Kumar RS, Sivakumar T, Sundaram RS, Sivakumar P, Nethaji R, Gupta M. Antimicrobial and antioxidant activities of Careya arborea Roxb. stem bark. Iranian Journal of Pharmacology and Therapeutics. 2006;5(1):35-41.

10. Vyas P, Thakar AB, Baghel MS, Sisodia A, Deole Y. Efficacy of Rasayana Avaleha as adjuvant to radiotherapy and chemotherapy in reducing adverse effects. Ayu. 2010;31(4):417-23.

11. D'Souza ND, Murthy NS, Aras RY. Projection of cancer incident cases for India -till 2026. Asian Pac J Cancer Prev. 2013;14(7):4379-86.

12. Francis D, Rita L. Rapid colorometric assay for cell growth and survival modifications to the tetrazolium dye procedure giving improved sensitivity and reliability. J Immunol Methods. 1986;89(2):271-7.

13. Vijayan P, Vinodkumar S, Dhanaraj SA, Mukherjee PK, Suresh B. In vitro cytotoxicity and antitumour properties of Hypericum mysorense and Hypericum patulum. Phytother Res. 2003;17: 952-6

14. Chang CC, Yang MH, Wen HM, Chern JC. Estimation of total flavonoid content in propolis by two complementary colorimetric methods. J Food Drug Anal. 2002;10:178-82.

15. Lee J, Koo N, Min DB. Reactive oxygen species, aging and antioxidative nutraceuticals. Comp Rev Food Sci Food Safety. 2004; 3: 21-32. 